\title{
Development of Synthetic Slag with Marble Waste and Calcium Aluminate Agents for Cast Iron Desulfurization
}

\author{
Felipe Fardin Grillo ${ }^{a *}$, Jorge Luís Coleti ${ }^{b}$, José Roberto de Oliveira ${ }^{c}$, Eduardo Junca ${ }^{a}$, \\ Rüdiger Deike ${ }^{d}$, Denise Crocce Romano Espinosa ${ }^{b}$
}

\author{
${ }^{a}$ Master's Program in Materials Science and Engineering, University of the Extreme South of Santa \\ Catarina, Criciúma, SC, Brazil. \\ ${ }^{b}$ Chemical Engineering Department, Polytechnic School of the University of São Paulo, \\ São Paulo, SP, Brazil. \\ ${ }^{c}$ Metallurgical Engineering Department, Federal Institute of Education, Science and Technology of \\ Espirito Santo, Vitória, ES, Brazil. \\ ${ }^{d}$ Institute of Technology of Metals, University of Duisburg-Essen, Duisburg, \\ Nordrhein-Westfalen, Germany.
}

Received: November 08, 2016; Revised: April 11, 2017; Accepted: June 11, 2017

\begin{abstract}
The aim of this work was to study the use of slags to desulfurize cast iron. It was proposed to use alumina instead of fluorspar. In addition, marble waste was used instead of lime. Simulations applying Thermo-Calc ${ }^{\circledR}$ software were carried out in order to obtain the theoretical phases using thermodynamic data. Then, a comparison between theoretical data and experimental tests were performed. Cast iron was melted in induction furnace at $1550^{\circ} \mathrm{C}$. Slags composed mainly for $\mathrm{CaO}$ and $\mathrm{Al}_{2} \mathrm{O}_{3}$ were used to desulfurize cast iron. The results showed that the desulphurization reaction was favored when the liquid phase was increased. Furthermore, it was found that cast iron desulfurization occurs by top slag mechanism. Furthermore, the desulfurization tests showed a decrease up to $90.10 \%$ in the sulfur content to the mixture containing conventional lime and $87.25 \%$ to the mixture RMF 15 . The slags obtained from marble waste contained $\mathrm{MgO}$, which it interfered negatively in the desulfurization yield. In addition, increasing the $\mathrm{CaO}$ particle diameter improved the desulfurization process. The desulphurization process more favored to particle size of 500-1000 $\mu \mathrm{m}$.
\end{abstract}

Keywords: Desulfurization, fluorspar, marble waste, cast iron.

\section{Introduction}

Desulfurization is one of the most important process involving cast iron and steel production. Cast iron desulfurization is performed during the manufacture of ductile iron castings in order to obtain spherical graphite morphology ${ }^{1,2}$. Several reagents are employed to remove sulfur, such as calcium, magnesium and sodium ${ }^{3}$. However, the desulfurization using wire of magnesium powder is related to high operating $\cos ^{4,5}$.

The main sulfur removal mechanism is the transfer of sulfur from the metal to the slag phase ${ }^{6}$. The low solubility of sulfur at high temperatures in the iron favors the formation of sulfur-rich slags. However, it is necessary add desulfurization agents such as $\mathrm{Ca}$ or $\mathrm{Mg}$ in order to form slag, which removes sulfur from the hot metal. The Equation 1 describes the sulfur transfer from the liquid metal to the slag.

$$
[S]+\left(0^{2-}{ }_{\text {slag }}\right) \leftrightarrow\left(S^{2-}\right)+\left[0_{\text {steel }}\right]
$$

Due to the difficulty to describe the activities of the ionic elements $\left(\mathrm{O}^{2-}\right.$ e $\left.\mathrm{S}^{2-}\right)$, a simplified approach to this issue is to recognize that the $\mathrm{CaO}$ in slag is the predominant

* e-mail: fgrillo@unesc.net desulfurization, as show Equation 2. Additionally, the desulfurization occurs with the formation of a stable sulfide.

$$
\begin{array}{r}
(\mathrm{CaO})_{(S)}+[S] \leftrightarrow(\mathrm{CaS})_{(S)}+[\mathrm{O}](2) \\
\Delta G^{0}=115358-38.66 T(\mathrm{~J} / \mathrm{mol})(3)
\end{array}
$$

The effect of carbon and silicon content in steel and cast iron are also mentioned during the desulfurization tests. The Equations 4 and 6 show this relationship ${ }^{7,8}$.

$$
\begin{aligned}
& (\mathrm{CaO})_{(S)}+[S]+[\mathrm{C}] \leftrightarrow \\
& (\mathrm{CaS})_{(S)}+C O_{(g)} \\
& \Delta G^{0}=87550-68.50 T(\mathrm{~J} / \mathrm{mol})(5) \\
& (\mathrm{CaO})_{(S)}+[\mathrm{S}]+1 / 2[\mathrm{Si}] \leftrightarrow \\
& (\mathrm{CaS})_{(S)}+(\mathrm{SiO})_{(S)} \\
& \Delta G^{0}=1280543-32.4 T(\mathrm{~J} / \mathrm{mol})(7)
\end{aligned}
$$

Thus, the marble waste can be an alternative to be a input in the desulfurization process of hot metal, since this waste contain high percent of $\mathrm{CaO}(70 \%)$ and $\mathrm{MgO}(20 \%)$. In Brazil, approximately 468 thousand tons of marble waste 
was generated in 2015. This waste can be consumed in the Brazilian steel industry if it was used as desulfurization agents.

The current study aims to adjust the composition of synthetic slags used in the cast iron desulphurization process in order to replace the magnesium for calcium oxide or marble waste as desulfurization agent. Furthermore, this study aims to compare the results obtained through computational thermodynamic software to the experimental results.

\section{Experimental}

\subsection{Marble waste characterization}

The marble waste characterization was performed by chemical analysis via energy dispersive X-ray fluorescence (EDXRF). The X-ray diffraction test was accomplished using a Rigaku diffractometer, Miniflex 300 model, equipped with $\mathrm{Cu} \mathrm{K} \alpha(\lambda=1,5418 \AA)$ tube. Step scan mode was applied to obtain the data. In addition, scan range of $3-90^{\circ}$, step width of $0.02^{\circ}$ and duration time of 5 seconds were used. A Netzsch thermobalance was used to performed the thermogravimetric analysis (TGA). The temperature range investigate was $25-1000^{\circ} \mathrm{C}$. It was adopted a heat rate of $10^{\circ} \mathrm{C} \mathrm{min}^{-1}$ under a flow of $50 \mathrm{~mL} \mathrm{~min}^{-1}$ of nitrogen. Scanning electron microscopy (SEM) assay was performed using a Philips XL-30 equipment in order to investigate the morphology of marble waste. Surface area was determined by BET (Brunauer-EmmettTelle) through accelerated surface area and porosimetry system (ASAP 2020) equipment. A pre-treatment up to $200^{\circ} \mathrm{C}$ by 24 hours was necessary to accomplish the tests. Additionally, size analyses was performed via mastersizer 2000. Such equipment uses laser diffraction technique to obtain the data.

\subsection{Synthetic slags compositions}

Table 1 shows the slags compositions used in the desulfurization tests.

The mixtures from CA1 to CA5 were produced using conventional lime-based slags and $\mathrm{Al}_{2} \mathrm{O}_{3}$ based slag.

The mixtures from 6 to 10 (ending with RM) were produced in order to replace the conventional lime on the slags by carbonate marble waste. The mixtures 11 and 12 (ending with CAF and RMF) were formulated with fluorspar in order to compare the results obtained with mixtures without $\mathrm{CaF}_{2}$.

\subsection{Desulphurization tests}

The desulfurization tests were performed using a mass of $1.4 \mathrm{~kg}$ of solid cast iron in each experiment. The mass of solid cast iron was put into a carbon crucible $(1000 \mathrm{~mL})$ and enveloped with a carbon ceramic blanket to decrease the heat loss. The set (carbon crucible and carbon ceramic blanket) was inserted in an alumina crucible in the induction
Table 1. Slags compositions used in cast iron desulfurization tests

\begin{tabular}{lcccccc}
\hline \multirow{2}{*}{ Mixtures } & \multicolumn{6}{c}{ Composition $(\mathrm{wt} \% *)$} \\
\cline { 2 - 7 } & $\mathrm{Al}_{2} \mathrm{O}_{3}$ & $\mathrm{CaO}$ & $\mathrm{MgO}$ & $\mathrm{SiO}_{2}$ & $\mathrm{Na}_{2} \mathrm{O}$ & $\mathrm{CaF}_{2}$ \\
\hline $\mathrm{CA} 1$ & 20.0 & 65.0 & 0.00 & 0.00 & 15.0 & 0.00 \\
$\mathrm{CA} 2$ & 25.0 & 65.0 & 0.00 & 0.00 & 10.0 & 0.00 \\
$\mathrm{CA} 3$ & 30.0 & 60.0 & 0.00 & 0.00 & 10.0 & 0.00 \\
$\mathrm{CA} 4$ & 25.0 & 60.0 & 0.00 & 0.00 & 15.0 & 0.00 \\
$\mathrm{CA} 5$ & 15.0 & 75.0 & 0.00 & 0.00 & 10.0 & 0.00 \\
$\mathrm{RM} 6$ & 15.49 & 50.47 & 18.21 & 4.21 & 11.62 & 0.00 \\
$\mathrm{RM} 7$ & 19.37 & 50.47 & 18.21 & 4.21 & 7.74 & 0.00 \\
$\mathrm{RM} 8$ & 23.54 & 47.46 & 17.13 & 3.96 & 7.91 & 0.00 \\
$\mathrm{RM} 9$ & 19.74 & 47.38 & 17.08 & 3.96 & 11.84 & 0.00 \\
$\mathrm{RM} 10$ & 11.25 & 56.26 & 20.29 & 4.69 & 7.50 & 0.00 \\
$\mathrm{CAF} 11$ & 30.0 & 60.0 & 0.00 & 0.00 & 0.00 & 10.0 \\
$\mathrm{RMF} 12$ & 23.68 & 47.37 & 17.08 & 3.95 & 0.00 & 7.89 \\
\hline W\% & & & & & &
\end{tabular}

*wt\%: weight percent.

furnace, and heated up to $1550^{\circ} \mathrm{C}$. The heating was controlled at $30^{\circ} \mathrm{C} \mathrm{min}-1$ from $25^{\circ} \mathrm{C}$ to $1550^{\circ} \mathrm{C}$. Figure 1 sketches out a schematic diagram of the induction furnace used in the experiments.

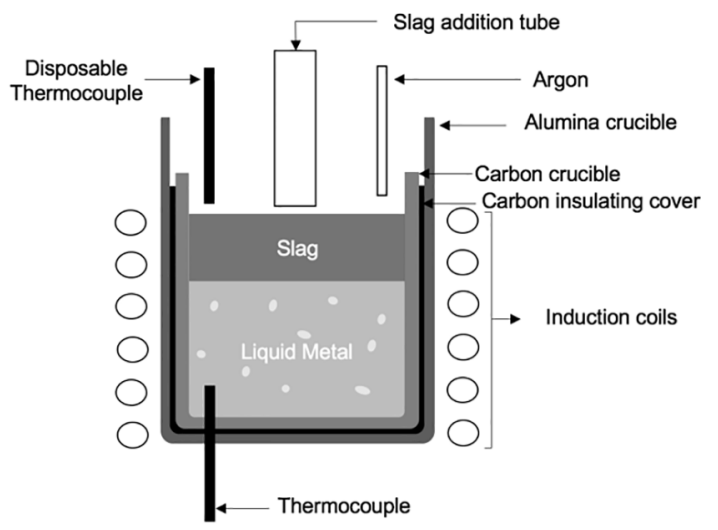

Figure 1. Schematic diagram of the induction furnace used in the experiments.

After complete melting of the cast iron, it was collected an aliquot of the liquid phase to obtain the initial content of sulfur, carbon, silicon and phosphorus (Table 2) via mass spectrometer. This step was carried out to calculate the desulphurization yield.

The addition of synthetic slag was splitted in three aliquot (containing the same mass) in order to increase the desulphurization efficient. The first aliquot was added right after the sample collected to chemical analysis. This stage was designated as time zero minute. Then, the second and third addition of synthetic slag were performed at 15 and 30 minutes, respectively.

To investigate the sulfur variation during the tests, aliquots were obtained from the bath at 5, 10, 15, 20, 25, 30, 35, 
Table 2. Initial composition of cast iron used to desulphurization tests.

\begin{tabular}{lccccc}
\hline \multirow{2}{*}{ Mixtures } & \multicolumn{5}{c}{ Chemical composition (wt \%) } \\
\cline { 2 - 5 } & $\mathrm{C}$ & $\mathrm{Si}$ & $\mathrm{P}$ & $\mathrm{S}$ & \\
\hline CA1 & 3.26 & 1.64 & 0.054 & 0.103 & \\
CA2 & 3.18 & 1.64 & 0.054 & 0.084 & \\
CA3 & 3.20 & 1.61 & 0.050 & 0.090 & \\
CA4 & 3.28 & 1.68 & 0.056 & 0.103 & \\
CA5 & 3.22 & 1.68 & 0.056 & 0.096 & \\
RM6 & 3.20 & 1.72 & 0.057 & 0.084 & 1.4 \\
RM7 & 3.16 & 1.72 & 0.053 & 0.084 & \\
RM8 & 3.24 & 1.69 & 0.052 & 0.082 & \\
RM9 & 3.32 & 1.73 & 0.057 & 0.087 & \\
RM10 & 3.37 & 1.7 & 0.064 & 0.091 \\
CAF11 & 3.25 & 1.71 & 0.064 & 0.101 & \\
RMF12 & 3.28 & 1.73 & 0.059 & 0.091 &
\end{tabular}

40 and 45 minutes. The samples obtained in each aliquots were analyzed via mass optic spectrometry to determine the content of sulfur. It is also important to mention that the bath agitation was promoted by induction furnace.

The initial and final content of sulfur were used to calculate the desulphurization yield $(\% \eta)$ via equation 10 . Where $\left[\% \mathrm{~S}_{\mathrm{i}}\right]$ and $\left[\% \mathrm{~S}_{\mathrm{f}}\right]$ are the initial and final sulphur content in the bath, respectively.

$$
\eta(\%)=\frac{\left[\% S_{i}\right]-\left[\% S_{f}\right]}{\% S_{i}} * 100
$$

The synthetic slags compositions presented in table 1 were also analyzed via Thermo-Calc ${ }^{\mathbb{B}}$ software in order to compare the theoretical equilibrium contents. Then, both liquid and solid fractions were also determined. The database SLAG3 was adopted to the simulated.

In addition, it was investigate the influence of lime particle size on desulfurization process. In this step, the lime was classified in three particles size $(500-1000 \mu \mathrm{m},<$ $100 \mu \mathrm{m}$ and $<20 \mu \mathrm{m}$ ) in order to produce the slags. It was also added $10 \mathrm{wt} . \%$ of fluorspar in each slag.

\section{Results and Discussion}

\subsection{Raw material characterization}

Table 3 shows the chemical analysis of marble waste and lime used to formulate the synthetic slags. The main component in the lime is $\mathrm{CaO}(99.9 \%)$, whereas marble waste contains as the mains components the $\mathrm{CaO}(39.00 \%)$ and $\mathrm{MgO}(14.56 \%)$. A loss on ignition of $42.08 \%$ was also observed. Figure 2 presents the X-ray pattern of marble waste, which shows that the marble waste is composed for calcium carbonate $\left(\mathrm{CaCO}_{3}\right)$, magnesium carbonate $\left(\mathrm{MgCO}_{3}\right)$ and silicon oxide $\left(\mathrm{SiO}_{2}\right)$. In addition, thermogravimetric
Table 3. Chemical components used on the production of synthetic slags.

\begin{tabular}{lcc}
\hline Elements & Marble Waste** (wt.\%) & Lime (wt. \%) \\
\hline $\mathrm{SiO}_{2}$ & 3.43 \\
$\mathrm{CaO}$ & 39.00 & 99.9 \\
$\mathrm{MgO}$ & 14.56 \\
$\mathrm{LOI}$ & 42.08 \\
*LOI: loss on ignition. ** Chemical composition used to determine \\
the slags compositions in Table 1.
\end{tabular}
the slags compositions in Table 1 .

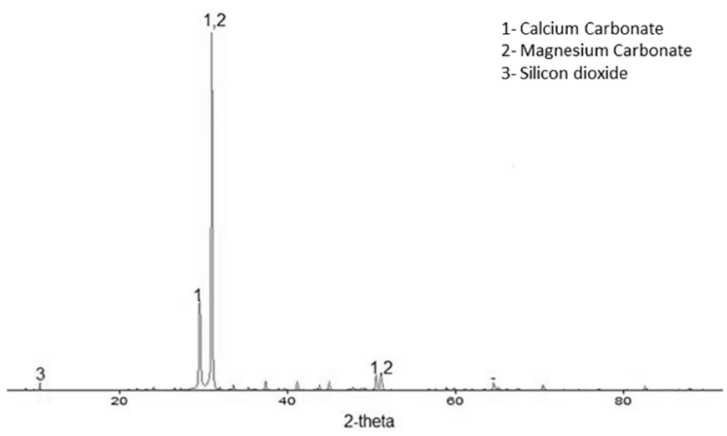

Figure 2. Marble waste X-ray diffractogram.

analysis (Figure 3) of marble waste shows a mass loss of $43.81 \%$ in the temperature range of $700^{\circ} \mathrm{C}$ to $820^{\circ} \mathrm{C}$. This fact is mentioned as the carbonates decomposing into $\mathrm{CaO}, \mathrm{MgO}$ and $\mathrm{CO}_{2}{ }^{9-11}$. Furthermore, the addition of marble waste into the cast iron at $1550^{\circ} \mathrm{C}$ will promote the decomposition of the carbonates to form $\mathrm{CO}_{2}$, which it can favor the bath agitation. However, the carbonates decomposition is endothermic, which it reduces the bath temperature, disfavoring the desulfurization reaction ${ }^{12}$.

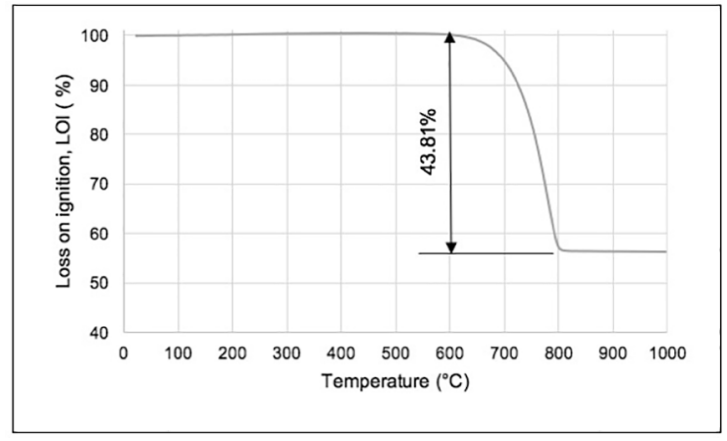

Figure 3. Marble waste thermogravimetry analysis.

Figure 4 shows images of scanning electron microscopy and EDS spectra obtained from the marble waste. It can be seen an angular morphology, coarse surface and cleavage profile. In addition, the EDS spectrum revealed that the main elements were $\mathrm{Ca}, \mathrm{Mg}, \mathrm{O}$ and $\mathrm{Si}$. The results show that calcium is present in greater proportion than other elements.

Additionally, analysis of particle size indicates that marble waste presented a cumulative d50 diameter of $48 \mu \mathrm{m}$. 


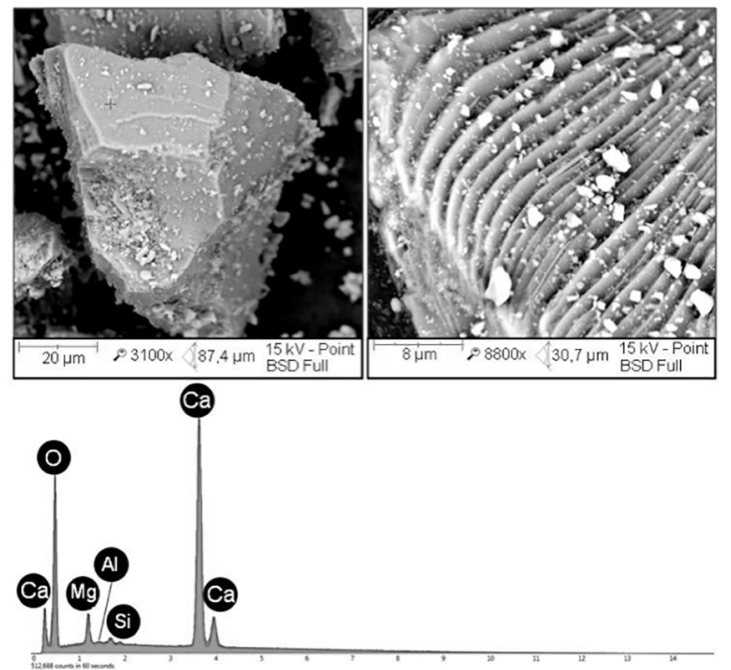

Figure 4. MEV backscattered electron images and EDS of marble waste.

The superficial area test indicates that the superficial area was $0.24 \mathrm{~m}^{2} / \mathrm{g}$. The lime size analysis shows that the $\mathrm{d} 50$ are about $16 \mu \mathrm{m}$ and superficial area of $1.52 \mathrm{~m}^{2} / \mathrm{g}$. Therefore, marble waste is able to substitute the calcium oxide in slags production for desulfurization of cast iron, since its chemical and physical characteristics were similar.

\subsection{Desulfurization experiment}

Table 4 shows the equilibrium contents in the cast iron after thermodynamics calculations via Thermo-Calc ${ }^{\circledR}$ and the desulfurization yield $\eta(\%)$.

The synthetics slags RM6 and RM7 (83.93\% and 85.63\% desulphurization yield, respectively) presented higher desulphurization yield than synthetics slags CA1 and CA2 (desulfurization yield of $82.52 \%$ and $84.64 \%$, respectively). However, the synthetics slags CA3, CA 4 and CA5 presented better desulphurization yield than the synthetics slags RM8, RM9 and RM10.
Such results indicate that addition of marble waste is a potential to the desulphurization of cast iron. However, increasing the content of marble waste in the synthetic slags decreased the desulphurization yield.

It was also noted that synthetics slags containing $\mathrm{CaF}_{2}$ (CAF11 and RMF12) presented lower values to equilibrium sulfur $\left(5.17 \mathrm{E}^{-05}\right.$ and $5.75 \mathrm{E}^{-5}$, respectively), which suggest a higher thermodynamic potential to desulfurization. However, kinetic parameter should be also considered to indicate the better synthetic slag ${ }^{13,14}$.

Figure 5 shows the sulfur variation as a function of time for slags containing conventional lime and slags containing marble waste. In general, the slags containing conventional lime (Figure 5A) reached the final sulfur content faster than the slags containing marble waste (Figure 5B), since these slags presented higher content of $\mathrm{MgO}$, which increases the percent of solid phase. It was also noted that the slags containing fluorspar (CAF11 and RMF12) reached the lesser content of sulfur $(0.01 \%)$ faster than the other slags (30 and 40 minutes, respectively). The presence of fluorspar decreases the slag melting temperature and increases the liquid phase percent, which increases metal/slag interface ${ }^{15}$.

Table 5 shows the liquid and solid phases obtained via Thermo-Calc ${ }^{\circledR}$ software from synthetics slags compositions. The thermodynamics software also indicates the composition of the solid phases formed during desulphurization process and sulfur content at equilibrium in the bath.

It was noted a linear relationship between the liquid phase and desulfurization yield, as it can be seem in Figure 6A and Figure $6 \mathrm{~B}$. The equations obtained were used as parameter to describe the behavior of slags CA1-CA5 (Figure 6A) and marble waste (Figure $6 \mathrm{~B}$ ) to desulfurization of cast iron by top slag.

The linear trend $\left(\mathrm{R}^{2}\right)$ was 0.96 to the conventional limebased slags (A) and 0.94 to the mixtures with addition of marble waste (B). In this case, increasing the liquid phase improves sulfur diffusion into the slag and the interface metal/ slag is more effective, which favors the desulfurization ${ }^{16}$.

Table 4. Equilibrium (wt \%) obtained for Thermo-Calc ${ }^{\circledR}$ in cast iron and desulfurization yield $(\eta(\%))$.

\begin{tabular}{cccccc}
\hline Mixture & {$\left[\% \mathrm{~S}_{\text {eq. }}\right]$} & {$\left[\% \mathrm{Si}_{\text {eq. }}\right]$} & {$\left[\% \mathrm{C}_{\text {eq. }}\right]$} & {$[\% \mathrm{Mn}]$} & $\eta(\%)$ \\
\hline CAF11 & $5.17 \mathrm{E}^{-05}$ & 1.61 & 3.19 & 0.53 & 90.10 \\
CA3 & $2.21 \mathrm{E}^{-04}$ & 1.59 & 3.18 & 0.53 & 89.81 \\
RMF12 & $5.75 \mathrm{E}^{-05}$ & 1.62 & 3.19 & 0.55 & 87.25 \\
RM8 & $3.95 \mathrm{E}^{-04}$ & 1.56 & 3.18 & 0.53 & 87.03 \\
CA4 & $1.74 \mathrm{E}^{-04}$ & 1.53 & 3.18 & 0.53 & 86.56 \\
RM7 & $1.36 \mathrm{E}^{-04}$ & 1.56 & 3.19 & 0.53 & 85.63 \\
RM9 & $3.46 \mathrm{E}^{-04}$ & 1.54 & 3.18 & 0.54 & 85.33 \\
CA2 & $6.30 \mathrm{E}^{-05}$ & 1.54 & 3.19 & 0.53 & 84.64 \\
RM6 & $1.49 \mathrm{E}^{-04}$ & 1.53 & 3.19 & 0.53 & 83.93 \\
CA1 & $6.41 \mathrm{E}^{-05}$ & 1.51 & 3.19 & 0.53 & 82.52 \\
CA5 & $6.30 \mathrm{E}^{-05}$ & 1.54 & 3.19 & 0.53 & 79.76 \\
RM10 & $6.26 \mathrm{E}^{-05}$ & 1.53 & 3.20 & 0.54 & 79.63 \\
\hline
\end{tabular}




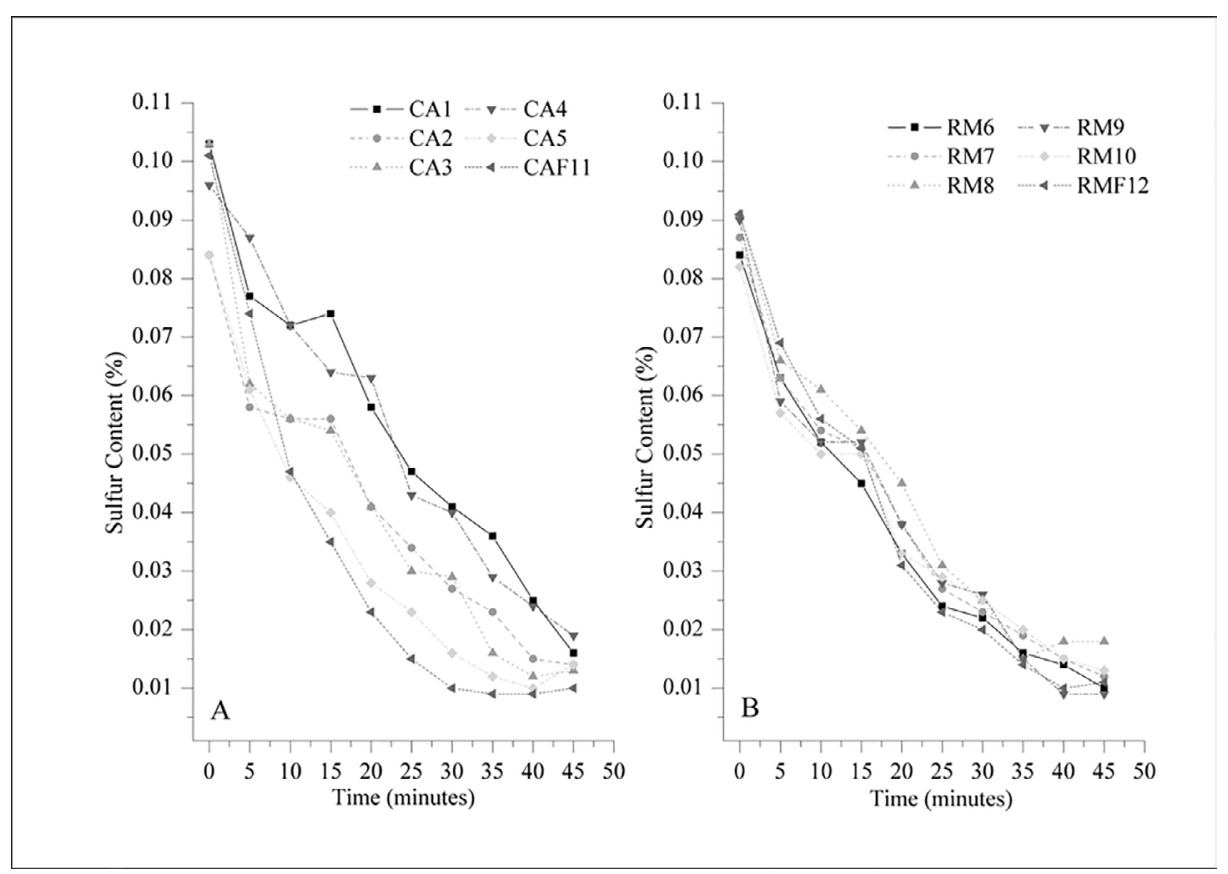

Figure 5. A- Sulfur variation as a function of time in the experiments with conventional lime. B- Sulfur variation as a function of time in the experiments with marble waste.

Table 5. Equilibrium calculations from initial mixtures of cast iron via Thermo-Calc ${ }^{\circledR}$.

\begin{tabular}{|c|c|c|c|c|c|c|c|}
\hline \multirow[t]{2}{*}{ Mixtures } & \multirow{2}{*}{$\begin{array}{l}\text { Liquid Phase } \\
\text { (wt \%) }\end{array}$} & \multirow{2}{*}{$\begin{array}{l}\text { Mass of the } \\
\text { Liquid Phase } \\
\text { (g) }\end{array}$} & \multirow{2}{*}{$\begin{array}{l}\text { Solid Phase } \\
\text { (wt \%) }\end{array}$} & \multicolumn{2}{|c|}{$\begin{array}{c}\text { Phases formed in the Solid } \\
\text { Phase (wt \%) }\end{array}$} & \multirow{2}{*}[\mathrm{S}_{\mathrm{eq}}]{$_{\text {liq }}$} & \multirow[t]{2}{*}{$\eta(\%)$} \\
\hline & & & & $\mathrm{CaO}$ & $\mathrm{MgO}$ & & \\
\hline CAF11 & 88.02 & 36.97 & 11.98 & 11.97 & 0 & 0.00057 & 90.10 \\
\hline CA3 & 82.74 & 34.75 & 17.26 & 17.26 & 0 & 0.00149 & 89.81 \\
\hline RMF12 & 82.39 & 29.99 & 17.61 & 4.14 & 13.47 & 0.00102 & 87.25 \\
\hline RM8 & 73.26 & 26.67 & 26.74 & 13.7 & 13.04 & 0.00354 & 87.03 \\
\hline CA4 & 75.18 & 31.58 & 24.82 & 24.82 & 0 & 0.00065 & 86.56 \\
\hline RM7 & 63.00 & 24.89 & 37.00 & 22.15 & 14.84 & 0.00433 & 85.63 \\
\hline RM9 & 67.14 & 24.44 & 32.86 & 19.84 & 13.01 & 0.00484 & 85.33 \\
\hline CA2 & 70.45 & 29.59 & 29.55 & 29.55 & 0 & 0.00175 & 84.64 \\
\hline RM6 & 56.17 & 22.19 & 43.83 & 28.78 & 15.04 & 0.00554 & 83.93 \\
\hline CA1 & 62.97 & 26.45 & 37.03 & 37.03 & 0 & 0.00344 & 82.52 \\
\hline CA5 & 46.05 & 19.34 & 53.95 & 53.95 & 0 & 0.00465 & 79.76 \\
\hline RM10 & 43.39 & 19.74 & 56.61 & 38.36 & 18.25 & 0.00751 & 79.63 \\
\hline
\end{tabular}

Figure 7 indicates that increasing the $\mathrm{CaO}$ content in the liquid phase increases the desulfurization yield. For synthetic slag prepared with conventional lime was noted a linear trend $(0.95)$ between the liquid phase and desulfurization yield. On the other hand, for slags prepared with marble waste, the linear trend was 0.659 , indicating that $\mathrm{MgO}$ can decrease the desulfurization process.

Figure 8 shows the effect of $\mathrm{MgO}$ on the desulfurization reaction of the cast iron.

It can be noted in the figure 8 that increasing the $\mathrm{MgO}$ content in slags with marble waste decreased the desulfurization efficience from $87,25 \%$ to $79,25 \%$. According to chemical analysis of marble waste, it was noted a higher content of $\mathrm{MgO}(14.56 \mathrm{wt} \%)$, which can influences the percente of liquid phase in the bath, and consequently, the desulfurization efficience. Thus, figure 9 shows the influence of $\mathrm{MgO}$ content on the percente of liquide phase to the slags.

Increasing the content of solid $\mathrm{MgO}$ in the slags decreased the liquid phase, since the $\mathrm{MgO}$ increases the melt point of the slag. Despite the fact that carbonate decomposition content no marble waste (Table 3 ) improved the desulfurization by playing an important role on the sulfur transfer mechanism 

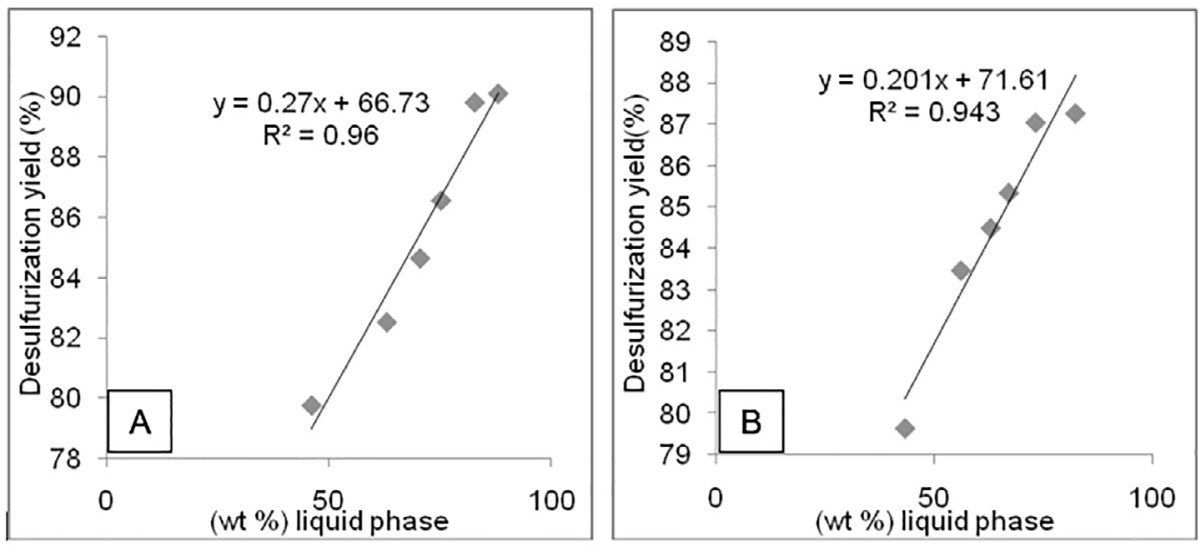

Figure 6. Relationship between liquid phase and desulfurization yield to the slags based in $\mathrm{CaO}-\mathrm{Al}_{2} \mathrm{O}_{3}$ (A) and marble waste $(\mathrm{B})$.

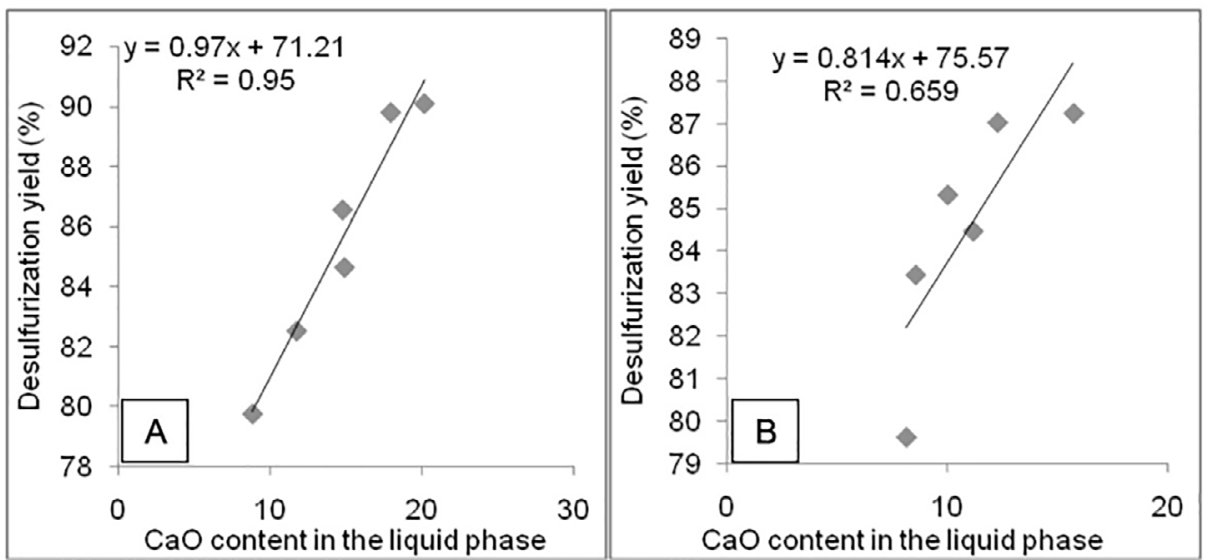

Figure 7. Relation between $\mathrm{CaO}$ content in the liquid phase and desulfurization yield of the slags based on conventional lime (A) and marble residue (B).

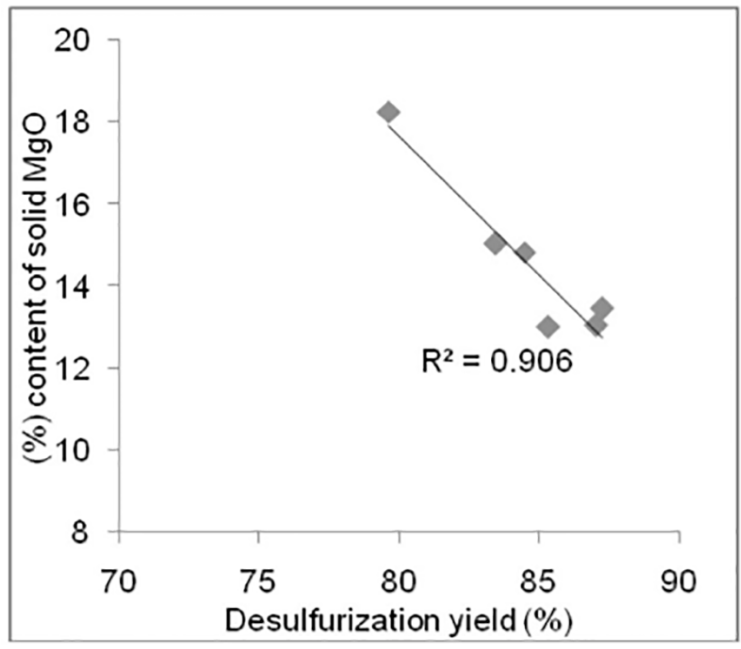

Figure 8. Relation between $\mathrm{MgO}$ content and desulfurization yield.

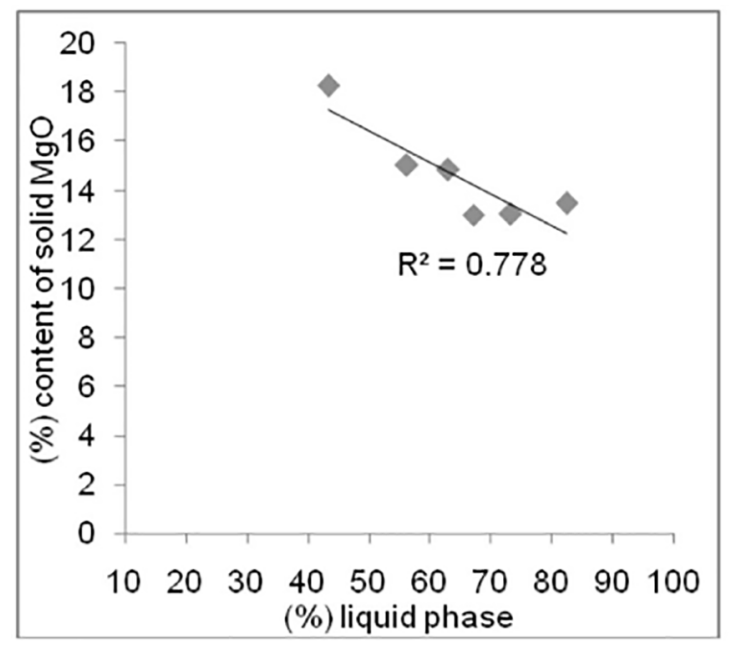

Figure 9. Graphics showing the $\mathrm{MgO}$ as a function of liquid phase and the desulfurization yield for all marble waste containing slags. 
to the interface hot metal-slag, the presence of solid $\mathrm{MgO}$ acts by retarding the process.

Based on these results, the application of marble waste together with conventional lime or even substituting dolomite can be an alternative to reduce the negative effect of $\mathrm{MgO}$ during the desulfurization.

\subsection{Tests to compare the substitution of fluorspar for $\mathrm{Al}_{2} \mathrm{O}_{3}$}

The tests to compare the substitution of fluorspar for $\mathrm{Al}_{2} \mathrm{O}_{3}$ with slags containing marble waste and conventional lime indicates that the synthetic slag CAF11 presented a desulphurization yield of $90.1 \%$, while the synthetic slag CA3 presented a desulphurization yield of $89.81 \%$. In this way, the substitution of fluorspar for $\mathrm{Al}_{2} \mathrm{O}_{3}$ might be viable. The slags containing marble waste (RMF12 and RM8) showed desulfurization yield of $87.0 \%$. This result suggests the marble waste as an alternative substitute to the conventional lime, since the yield is close to that yield obtained for slags with conventional lime.

\subsection{Effect of particle size}

Figure 10 shows the influence of particle size in the desulphurization process.

It can be noted in figure 10 that the desulfurization process more favored to particle size of 500-1000 $\mu \mathrm{m}$. It may be contradictory, since decreasing the particle size increases the surface area. This fact can the explained by agglomeration phenomenon observed during the experiments (Figure 11).

It was observed that slags with particle size of $20 \mu \mathrm{m}$ and $100 \mu \mathrm{m}$ sintered in contact with the liquid metal, forming agglomerated particles. Slags contained particle size in the range of $0.5-1.0 \mathrm{~mm}$ did not form agglomerated particles. This result was similar to that found by McFeaters and Fruehan ${ }^{17}$.

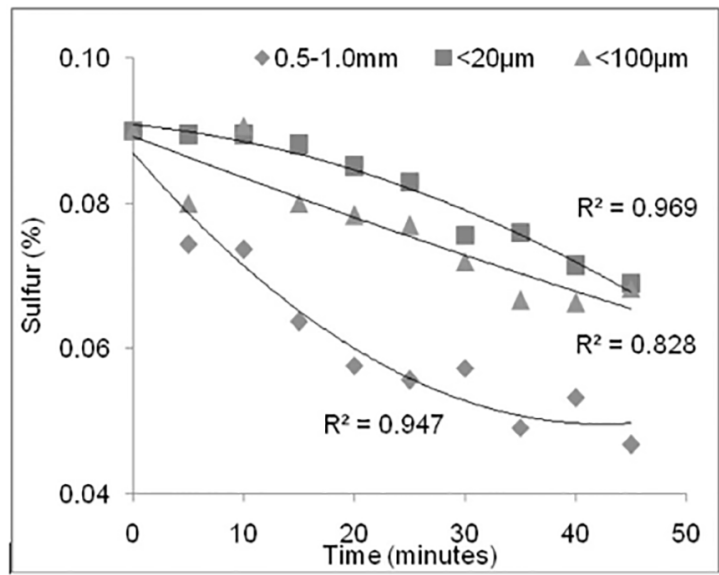

Figure 10. Content of sulfur as a function of time.

\section{Conclusions}

The mixtures with addition of marble waste that obtained the best desulfurization yield were RMF15 and RM8 (87.25\% and $87.03 \%$ ). The best results obtained from conventional lime were CAF11 and CA3 (90.10\% and 89.81\%). The computational thermodynamic analysis showed that the $\mathrm{MgO}$ present in the marble waste decreased the liquid phase fraction in the slag, once increasing liquid phase favored both sulfur mass transport into the slag and in the metal/ slag interface, raising the mixtures desulfurization yield. The computational thermodynamic analysis also showed lower sulfur equilibrium for the mixtures CAF11, RMF12, CA5 and RM10, since the fluorspar increased the liquid phase fraction in the slag. Increasing the $\mathrm{CaO}$ particle diameter improved the desulfurization process. Particle with diameter in range of 20 to $100 \mu \mathrm{m}$ were sintered after addition on the liquid metal, decreasing the desulfurization. The substitution of fluorspar for $\mathrm{CaO}-\mathrm{Al}_{2} \mathrm{O}_{3}$ system slags is viable. Thus, depending on the sulfur content to be reached,

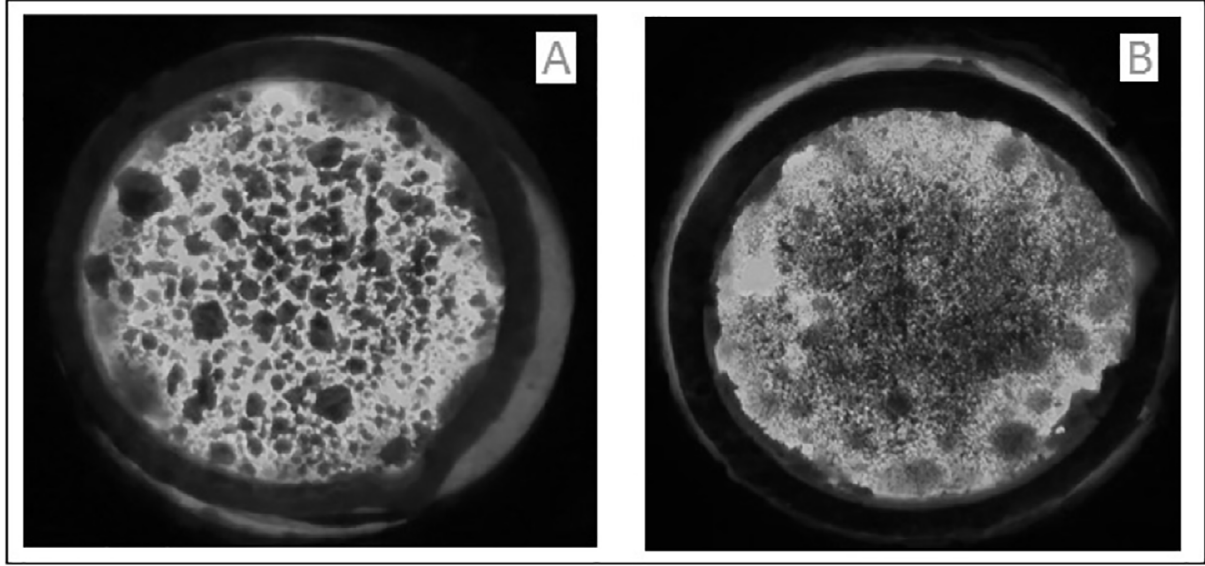

Figure 11. Image obtained after 5 minutes of desulphurization tests with lime: (A) $<100$; (B) range of $0.5-1.0 \mathrm{~mm}$. 
marble waste may be a viable economic and environmental alternative to replace lime.

\section{References}

1. Hara T, Kitagawa T, Kuroki K, Saikawa S, Terayama K, Ikeno S, et al. Morphologies of Some Graphites in Ductile Cast Irons. Materials Transactions. 2014;55(9):1500-1505.

2. Nakae H, Igarashi Y. Influence of Sulfur on Heterogeneous Nucleus of Sphroidal Graphite. Materials Transactions. 2002;43(11):2826-2831.

3. Dyudkin DA, Grinberg SE, Marintsev SN. Mechanism of the Desulfurization of Pig Iron by Granulated Magnesium. Metallurgist. 2001;45(3):150-155.

4. Nita PS, Butnariu I, Constantin N. The efficiency at industrial scale of a thermodynamic model for desulphurization of aluminium killed steels using slags in the system $\mathrm{CaO}-\mathrm{MgO}-\mathrm{Al}_{2} \mathrm{O}_{3}-\mathrm{SiO}_{2}$. Revista de Metalurgia. 2010;46(1):5-14.

5. Grillo FF, Coleti JC, Oliveira JR, Tenório JAS, Junca E, Espinosa DCR. Use of Computational Thermodynamics in the Analysis of Hot Metal Desulphurization with Slags Based on Marble Waste and Sodalite. Materials Transactions. 2016;57(8):1332-1338.

6. Pretorius EB, Carlisle RC. Foamy Slag Fundamentals and their Practical Application to Electric Furnace Steelmaking. In: Proceedings of Electric Furnace and $16^{\text {th }}$ Process Technology Conference; 1998 Nov 15-18; New Orleans, LA, USA. p. 275-292.

7. Visser HJ, Boom R. Advanced Process Modelling of Hot Metal Desulphurisation by Injection of $\mathrm{Mg}$ and $\mathrm{CaO}$. ISIJ International. 2006;46(12):1771-1777.

8. Brahma D, Boom R. Fundamentals of Steelmaking Metallurgy. Hertfordshire: Prentice Hall International; 1993.
9. Eliche-Quesada D, Corpas-Iglesias FA, Pérez-Villarejo L, Iglesias-Godino FJ. Recycling of sawdust, spent earth from oil filtration, compost and marble residues for brick manufacturing. Construction and Building Materials. 2012;34:275-284.

10. Mehta D, Mondal P, George S. Utilization of marble waste powder as a novel adsorbent for removal of fluoride ions from aqueous solution. Journal of Environmental Chemical Engineering. 2016;4(1):932-942.

11. Aliabdo AA, Elmoaty MA, Auda EM. Re-use of waste marble dust in the production of cement and concrete. Construction and Building Materials. 2014;50:28-41.

12. Aguiar FN, Grillo FF, Tenório JAS, Oliveira JR. Hot metal desulfurization by marble waste and fluorspar. REM: Revista Escola de Minas. 2012;65(2):233-240.

13. Niedringhaus JC, Fruehan RJ. Reaction mechanism for the $\mathrm{CaO}-\mathrm{Al}$ and $\mathrm{CaO}-\mathrm{CaF}_{2}$ desulfurization of carbon-saturated iron. Metallurgical Transactions B. 1988;19(2):261-268.

14.Grillo FF, Sampaio RA, Viana JF, Espinosa DCR, Oliveira JR. Analysis of pig iron desulfurization with mixtures from the $\mathrm{CaO}$-Fluorspar and $\mathrm{CaO}$-Sodalite system with the use of computational thermodynamics. REM: Revista Escola de Minas. 2013;66(4):461-465.

15. Matsuzawa A, Harada H. Effect of Flux Composition on Desulfurization Reaction Rate of Molten Steel. In: 2013 AISTech Conference Proceedings; 2013 May 6-9; Pittsburgh, PA, USA. p. 333-340.

16. Fruehan RJ. Desulfurization of liquid steel containing aluminum or silicon with lime. Metallurgical Transactions $B$. 1978;9(2):287-292.

17. McFeaters LB, Fruehan RJ. Desulfurization of bath smelter metal. Metallurgical Transactions B. 1993;24(3):441-447. 